\title{
Assessing the Nutritional Condition of The Elderly: Perspectives of Trained Health Workers and Significant Others in Countryside in Indonesia Inputs to an Action Plan
}

Menilai Kondisi Nutrisi Lansia: Perspektif Tenaga Kesehatan Terlatih dan Orang Lain yang Signifikan di Pedesaan di Indonesia Input ke Rencana Aksi

\author{
Fransisca Winandari \\ email: sisca@stikesbethesda.ac.id \\ STIKES Bethesda Yakkum Yogyakarta
}

\begin{abstract}
Background: Nutrition plays an important role in health maintenance, rehabilitation, and prevention and control of disease for the elderly. If undetected, nutritional problems among the elderly may result in more rapid deterioration of health and early death.
\end{abstract}

Methods: In this study, the researcher conducted descriptive correlational design to describe the perspectives of trained health workers and significant others on the nutritional condition of the elderly in terms of nutritional screening, nutritional assessment, and nutritional indication score.

Results: The population of this study is the trained health workers in Bambanglipuro and the significant others of the elderly who met the inclusion criteria. There are 50 of trained health worker respondents and 112 significant other respondents. Their assessment was assessed by themselves and tested significant differences using the T-test. All the computed $t$ values were less than $T$ values of 1.96. This result shows that the null hypothesis is accepted, meaning there is no significant difference between the assessment of the trained health worker respondents and the significant other respondents on the nutritional condition of the elderly. It proved that the significant others completely knew about the nutritional condition of the elderly.

Conclusions: Proposed action plan can be applied for enhancement of the nutritional condition of the elderly, such as to conduct a lecture related to the importance of assessing the physical problems of the patient, conduct a lecture related to the importance of assessing the patient's mode feeding, conduct a training workshop related how to measure Calf Circumference and Mid-arm Circumference (MAC).

Keywords: Nutritional screening, Nutritional assessment, Nutritional indication score.

\section{INTRODUCTION}

The number of elderly people worldwide will dramatically increase over the next decades. A study was found that the world's elderly population is exploding, with the number of people aged 65 and over expected to more than double by 2050 (Davies, 2016). Biological aging and disablement processes occur continuously and varies between individuals. Many factors affect individual aging and there is a large heterogeneity between individuals. Social, economic, physiological and psychological changes with aging have effects on eating patterns and nutritional status. 
SOEPRA Jurnal Hukum Kesehatan

TERAKREDITASI RISTEKDIKTI Peringkat 4

ISSN:2548-818X (media online) Vol. 6 (1) Juni 2020

Good nutrition and physical activity are health promoting lifestyle approaches in the elderly population. An inadequate nutrition contributes to sarcopenia, frailty, loss of functions and the progression of diseases in elderly people. Nutritional status is influenced by medical, physiological, psychological and social variables. Encouraging better nutrition and physical exercise is a cost effective way of decreasing progression of age related diseases (Morley, 2011). As people age, adequate nutrition promotes the maintenance of health, physical performance and psycho-social well-being (Bates et al, 2011).

Malnutrition has been recognized as a common problem among aged residents living in institutional care facilities. It is associated with certain diseases and impaired functioning, but less is known about its relationship with nutrition intake and nutritional care among aged residents (Milne et al, 2011). The assessment of the nutritional status of elderly people should be part of their care (Cowan et al, 2011). There are many tools for identifying the nutritional risks, but the most extensively evaluated tool is the Mini Nutritional Assessment -test (MNA) according to Hamirudin, Charlton, Walton (2016). Furthermore in addition, Malnutrition Universal Screening Tool (MUST) was originally designed for residential and community settings, however, it has now been validated in the acute setting, allowing screening to occur across the continuum of care (BPAC, 2011).

Nutritional advice for elderly residents and patients should focus on weight maintenance. Not all elderly individuals are the same with regard to appropriate nutritional interventions, however. The intervention for healthy elderly people should differ from those who are frail, from those with dementia, and from those who are at the end of their lives (Morley, 2011).

\section{BACKGROUND}

Indonesia has contributed significantly to the accelerated growth of the elderly population worldwide. Globally, Indonesia has the fifth-largest elderly population in the world. In 2012, there were nearly 21 million older people. Life expectancy has increased dramatically, from 45 in 1970 to 69.2 for males and 71 for women in 2010. At the same time, the birth rate has declined, resulting in an ageing population. It is estimated that by the year 2020, aging population in Indonesia will reach 11.34 per cent of total population. Moreover, the UN has predicted that the percentage of Indonesians over 60 years old will reach 25 percent in 2050 or nearly 74 million elderly people. Several provinces have a greater number of elderly people than the national average, and Yogyakarta has the nation's largest elderly population (Nasir, 2015).

For the past three decades, Indonesia has made significant progress in economic and human development, which has resulted in better health conditions and longer life expectancy, creating a growing population of older people. Population aging should be seen as a direct result of successes in development programs such as nutrition among elderly.

\section{METHODS}

\section{Population, Sample and Sampling Technique}

This study was conducted in work area of Bambanglipuro Public Health Facility, Bantul, Yogyakarta, Indonesia. Population in this study are the trained health workers in Bambanglipuro and the significant others of the elderly from the said area. There were 50 of trained health worker respondents who met the criteria inclusion. The criteria inclusion of trained health worker are: 
SOEPRA Jurnal Hukum Kesehatan

TERAKREDITASI RISTEKDIKTI Peringkat 4

ISSN:2548-818X (media online) Vol. 6 (1) Juni 2020

1. Man or woman $\geq 30$ years old, chosen by the community and trained by Professional Health Care to deal with health problems of individuals and society, as well as working in a place that is close to the delivery of health services.

2. Was able to assess nutritional status to elderly

3. Originally living in the study area and available during data collection

4. Willing to be respondent in the study

The researcher used retrospective design based from the identification of respondents from historical data that available in Bambanglipuro Public Health Facility. The elderly who seek consultation with their significant other in Bambanglipuro Public Health Care Facility from the period of January to February are 183. Researcher used Slovin's formula to minimize samples and got 126 samples. During data collection, there were 112 significant other respondents who met the inclusion criteria.

The inclusion criteria, which are:

1. Significant other (a person whose close relationship with the elderly affects that individual's behavior and attitudes. Usually a family member, spouse, child, employer, coworker, friend, who serves as a role model or whose acceptance and approval is sought).

2. Originally living in the study area and available during data collection

3. Willing to be a respondent in the study.

4. Do not have a hearing problem or any cognitive problem.

5. Can communicate verbally.

\section{RESEARCH INSTRUMENT}

Data collection in this study used a questionnaire as a tool. A Nutritional Health Care Practices questionnaire is adopted from Mini Nutritional Assessment (MNA) by Nestlé Nutrition Institute retrieved on 2017 from http://www.mna-elderly.com/. Some modifications were done by the researcher specifically in nutritional assessment categories, there were sentence modification and additional questions in nutritional screening about assessing of physical problems of the patient also in nutritional assessment about assessing the economical of the patient to buy food that they need. Researcher already sent a letter for asking permission to use the MNA as a tool, and got a response letter already. The Nutritional Health Care Practices questionnaire consists of 21 questions (Nutritional screening 6 items, Nutritional assessment 10 items and Nutritional indication score 5 items). The researcher used Five-point Likert's scale for the response of the respondents of the Nutritional Health Care Practices (1=never to 5=always).

\section{Summary}

The assessment of the trained health worker respondents on nutritional condition of the elderly with their corresponding weighted mean and verbal interpretations are follows: nutritional screening overall mean was 3.59 interpreted as often, nutritional assessment overall mean was 3.58 interpreted as often, nutritional indicator score overall mean was 3.19 interpreted as often.

The assessment of the significant other respondents on the nutritional condition of the elderly with their corresponding weighted mean and verbal interpretations are follows: nutritional screening overall mean was 3.19 interpreted as sometimes, nutritional assessment, overall mean was 3.07 interpreted as sometimes, nutritional indicator score, overall mean was 2.66 interpreted as sometimes. 
Table 1. Summary of T-Test Values on the Significant Difference between the Assessment of the Trained Health Worker Respondents and the Assessment of the Significant Other Respondents on the Nutritional Condition of the Elderly

\begin{tabular}{ll|l|l|l|l}
\hline \multicolumn{1}{c|}{ Areas } & Computed t & T value & $\begin{array}{c}\text { level of } \\
\text { Significant }\end{array}$ & \multicolumn{1}{c}{ Decision } \\
\hline I. & Nutritional Screening & 1.168362 & 1.96 & $5 \%$ & Accept Ho \\
\hline II. & Nutritional Assessment & 1.738821 & 1.96 & $5 \%$ & Accept Ho \\
\hline III. Nutritional Indicator Score & 0.535706 & 1.96 & $5 \%$ & Accept Ho \\
\hline
\end{tabular}

The significant difference between the assessment of the trained health worker respondents and the significant other respondents on the nutritional condition of the elderly based on the T-test statistical treatment with a 0.05 was found that in term of nutritional screening got computed $t$ of 1.168362, in term of nutritional assessment got computed $t$ of 1.738821 , in term of nutritional indicator score got computed $t$ of 0.535706 . All the computed $t$ values was less than $T$ values of 1.96. This result shows that the null hypothesis are accepted, meaning there is no significant difference between the assessment of the trained health worker respondents and the significant other respondents on the nutritional condition of the elderly. It proved that the significant other were completely know about nutritional condition of the elderly.

Based from the results of this study, the inputs for an action plan was proposed.

\section{CONCLUSIONS}

Based on this study findings, the following conclusions were derived:

1. The assessment of the trained health worker respondents on nutritional condition of the elderly, in terms of: nutritional screening and nutritional assessment are good, but for nutritional indicator score is fair.

2. The assessment of the significant other respondents on the nutritional condition of the elderly, in terms of: nutritional screening; nutritional assessment; nutritional indicator score are fair.

3. There is no significant difference between the assessment of the trained health worker respondents and the significant other respondents on the nutritional condition of the elderly.

4. Proposed action plan can be apply for enhancement of the nutritional condition of the elderly, such as: conduct a lecture related to the importance of assessing the physical problems of the patient, conduct a lecture related to the importance of assessing the patient's mode feeding, conduct a training workshop related how to measure Calf Circumference and Mid-arm Circumference (MAC). 


\section{RECOMMENDATIONS}

1. Conduct a lecture related to the importance of assessing the physical problems of the patient (lecture topic: Physical Problem in Elderly) provided by professional health worker in Bambanglipuro Public Health Facility.

2. Conduct a lecture related to the importance of assessing the patient's mode feeding (lecture topic: Geriatric Swallowing and Feeding Assessment and Intervention) provided by professional health worker in Bambanglipuro Public Health Facility.

3. Conduct a training workshop related how to measure: Calf Circumference and Midarm Circumference (MAC) provided by professional health worker in Bambanglipuro Public Health Facility.

4. The future researcher can expand the variable of the study, specifically related to the nutritional health condition of the elderly.

\section{ACKNOWLEDGEMENTS}

The researcher would like to thank the respondents who participated in this study for theirs willingness in taking time to complete the questionnaires. And special thanks go to the Ministry of Higher Education, Indonesia, and Bethesda Yakkum Health Science Institution for suporting during the process of this research study.

\section{REFERENCES}

Dodd, Judith L. (2015). Krause's Food \& the Nutrition Care Process (Nutrition in Adult Years). Edition 13. Philippines: Elsevier.

Wellman, Nancy S and Kamp, Barbara J. (2015). Krause's Food \& the Nutrition Care Process (Nutrition in Aging). Edition 13. Philippines: Elsevier.

Adioetomo, S. M., \& Mujahid, G. (2014). Indonesia on the Threshold of Population Ageing, (1).

Amsden, Karen L., Hamilton, Anna Allen., Hollin, Charla. (2012). Basic Geriatric Nursing. Fifth Edition. China: Elsevier.

Jett, Kathleen F. (2014). Gerontological Nursing \& Healthy Aging (Introduction to Healthy Aging). Fourth Edition. United States of America: Elsevier.

Jett, Kathleen F. (2014). Gerontological Nursing \& Healthy Aging (Theories of Aging and Physical Changes). Fourth Edition. United States of America: Elsevier.

Suominen, M. (2007). Nutrition and Nutritional Care of Elderly People in Finnish Nursing Homes and Hospitals.

Thouty, Theris A. (2014). Gerontological Nursing \& Healthy Aging (Gerontological Nursing History, Education, and Roles). Fourth Edition. United States of America: Elsevier.

Thomson, Kathryn H. (2015). Gerontology for The Health Care Professional (Nutrition and Aging). Third Edition. United States of America: Jones \& Bartlett Learning. 
Allen, M. (2016). Knowledge, attitudes and practices in the provision of nutritional care, (November). https://doi.org/10.12968/bjon.2011.20.10.615

Best Practice Advocacy Centre New Zealand. (2011). Strategies to improve nutrition in elderly people. Retrieved from http://www.bpac.org.nz/BPJ/2011/may/docs/bpac_prescription_foods_elderly_pa ges_20-34.pdf

Cowan DT, Roberts JD, Fitzpatrick JM, While AE, Baldwin J. (2011). Nutritional status of older people in long term care settings: current status and future directions. Research Fellow, Ageing and Health Section, Florence Nightingale School of Nursing and Midwifery, King's College London, UK. david.t.cowan@kcl.ac.uk

Davies, Madlen. (2016). The Global Elderly Explosion: Number of Old People is Rising Faster than Ever - and Will Double in 30 Years. Published: 02:07 Gmt, 29 March 2016 | Updated: 19:21 Gmt, 29 March 2016. Retrieved from http://www.dailymail.co.uk/health/article-3513167/Global-elderly-populationexploding-US-report.htmln

Hailemariam, H., Singh, P., Fekadu, T. (2016). Evaluation of Mini Nutrition Assessment (MNA) Tool among Community Dwelling Elderly in Urban Community of Hawassa city, Southern Ethiopia. Ethiopia: International Journal of Behavior Nutrition and Physical Activity. March 2005 - Volume 105 - Issue 3 - pp 40-50. Retrieved from http://journals.Iww.com/ajnonline/Fulltext/2005/03000/Nutrition_in_Older_Adult s_Intervention_and.20.aspx

Hamirudin, Aliza Haslinda., Charlton, Karen E., Walton, Karen L. (2016). Outcomes related to nutrition screening in community living older adults: a systematic literature review. University of Wollongong, Australia. Research Online.

Iqbal W, dkk. 2006. Ilmu Keperawatan Komunitas 2. Jakarta: CV. Sagung Seto. Jogiyanto,

Jyväkorpi, S. (2016). Nutrition of Older People and The Effect of Nutritional Interventions on Nutrient Intake, Diet Quality and Quality of Life.

Legi, N.N., Fred Rumagit, A.B. Montol, and Riaty Lule. 2015. Faktor Yang Berhubungan Dengan Keaktifan Kader Posyandu Di Wilayah Kerja Puskesmas Ranotana Weru. Gizido 7(2): 429-36.

Leslie, W., \& Hankey, C. (2015). Aging, Nutritional Status and Health, 648-658. https://doi.org/10.3390/healthcare3030648

Martin, Louise,. Leveritt, Michael., Dabrow, Ben., Ball, Lauren. (2013). The Self-Perceived Knowledge, Skills and Attitudes of Australian Practice Nurses in Providing Nutrition Care To Patients With Chronic Disease. Family Practice, 2013, Vol. 00, No. 00, 1-8. DOl:10.1093/fampra/cmt070. Retrieved from https://espace.library.uq.edu.au/view/UQ:321157/UQ321157_fulltext.pdf 
Milne AC, Avenell A, Potter J. (2011). Meta-analysis: protein and energy supplementation in older people. Health Services Research Unit, University of Aberdeen, Aberdeen, Scotland, United Kingdom.a.c.milne@abdn.ac.uk

Morley, Hickson. (2011). Malnutrition and ageing. DOI:10.1136/pgmj.2005.037564

Mostert, H., Meijers, U., Halfens, R., Mijnarends, D., \& Jos. (2013). A feedback system to improve the quality of nutritional care. Nutrition, 29(7-8), 1037-1041. https://doi.org/10.1016/j.nut.2013.02.007

Nasdia, Fredian Tony. (2015). Sosiologi Umum. Indonesia: Yayasan Pustaka Obor.

Nasir, Sudirman. (2015). Indonesia at 70: Prepare For Aging Population. The Jakarta Post. Retrieved from http://www.thejakartapost.com/news/2015/08/15/indonesia-70prepare-aging-population.html

Nufrika. (2011). Faktor-Faktor yang Berhubungan Dengan Status Gizi pada Lansia Di Pusat Pelayanan Sosial Lanjut Usia Mappakasunggu Kota Parepare. Makasar: Program Studi Ilmu Keperawatan Fakultas Kedokteran Universitas Hasanuddin.

Nurayu, Aldisa Wida. 2013. "Hubungan Tingkat Pengetahuan, Pendidikan, Usia Dan Lama Menjadi Kader Posyandu Dengan Kualitas Laporan Bulanan Data Kegiatan POSYANDU."

Pedro, MRA; Benavides, RC; Barba, CVC. (2011) Dietary Changes and health implications: An emerging double burden of under- and over-nutrition. FAO Food and Nutrition Paper 84. Food and Agriculture Organization of the United Nations, Rome. Retrieved http://www.fao.org/docrep/o09/a0442e/a0442eop.htm\#TopOfPage.

Persenius, M Wentzel. (2011). Nutritional Nursing Care "Nurses' Interactions with the Patient, The Team and The Organization". Faculty of Social and Life Sciences Nursing Science. Karlstad University Studies. Retrieved from https://www.divaportal.org/smash/get/diva2:37886/FULLTEXT01.pdf

Soderhamn, U., \& Lindstro, M. B. (2008). Self-care ability and sense of coherence in older nutritional at-risk patients, 96-103. https://doi.org/10.1038/sj.ejcn.1602691

Sodarsono, 2010. Hubungan Motivasi dan Pendidikan Kader Dengan Kinerja kader Posyandu di Wilayah Kerja Puskesmas Talun kabupaten Blitar.

Suominen, M. H., Sandelin, E., Soini, H., \& Pitkala, K. H. (2009). How well do nurses recognize malnutrition in elderly patients?, 292-296. https://doi.org/10.1038/sj.ejcn.1602916

Sutiani, Ria, Zulhaida Lubis, and Albiner Siagian. 2014. Description Of Cadres Knowledge And Skills In Monitoring The Growth Of Infant And Under Five Children In Puskesmas Desa Lalang 2014.

(2014). Ageing Population in Indonesia. Posted on 27 March 2014. Retrieved from http://ageingasia.org/ageing-population-indonesia1/ 
BAPEN. (2016). Screening and MUST. Retrieved from http://www.bapen.org.uk/screening-and-must/must

Best Practice Advocacy Centre New Zealand (BPAC). (2011). Strategies to improve nutrition in elderly people. Retrieved from http://www.bpac.org.nz/BPJ/2011/may/docs/bpac_prescription_foods_elderly_pa ges_20-34.pdf

Marpaung, Budhianto. (2014). Inilah Menu yang Tepat untuk Lansia. Retrieved from http://www.jawaban.com/read/article/id/2014/04/12/66/140411135104/Inilah-MenuMakanan-yang-Tepat-Untuk-Lansia.

Davies, Madlen. (2016). The Global Elderly Explosion: Number of Old People is Rising Faster than Ever - and Will Double in 30 Years. Published: 02:07 Gmt, 29 March 2016 | Updated: 19:21 Gmt, 29 March 2016. Retrieved from http://www.dailymail.co.uk/health/article-3513167/Global-elderly-populationexploding-US-report.htmln

DEPKES RI. (2012). Retrived from http://www.depkes.go.id/folder/view/01/structurepromosi-kesehatan-pedoman-dan-buku.html

Dinas Kesehatan Yogyakarta. (2012). Lampiran profil kesehatan (Yogyakarta) Tahun 2011. Yogyakarta: Dinkes Yogyakarta

Gonzalo, A. (2011). Virginia Henderson "The Principles and Practice of Nursing". Tetrieved from http://nursingtheories.weebly.com/virginia-henderson.html

KESMAS. (2014). Kader Posyandu: Pengertian, Syarat dan Peran Kader Posyandu. Retrieved from http://www.indonesian-publichealth.com/kader-posyandu-2/

Lita, Villalon., Manon, Laporte., \& Natalie, Carier. (2013). Nutritional screening among seniors in health care institutions: comparison between the institutions Francophones and Anglophones. Retrieved from http://europepmc.org/abstract/med/24300319

Nasir, Sudirman. (2015). Indonesia at 70: Prepare For Aging Population. The Jakarta Post. Retrieved from http://www.thejakartapost.com/news/2015/08/15/indonesia-70prepare-aging-population.html

Nestle Nutrition. (2010). Mini Nutritional Assessment. Retrieved from http://www.mnaelderly.com/forms/MNA_english.pdf.

Nurul. (2014). Kesehatan Kota Depok, Perlunya Laki-Laki Jadi Kader Posyandu dan

Setiawat, Resny (2012). Gizi pada Lansia. Retrieved from https://resnysetiawati.wordpress.com/2012/05/22/gizi-pada-lansia/.

Pedro MR, Barba CV. (2016). Nutritional issues and status of older persons of the Philippines: the IUNS, CRONOS and other studies. Retrieved from https://www.ncbi.nlm.nih.gov/pubmed/11426288 
SOEPRA Jurnal Hukum Kesehatan

TERAKREDITASI RISTEKDIKTI Peringkat 4

ISSN:2548-818X (media online) Vol. 6 (1) Juni 2020

PHILSPEN. (2016). the PhilSPEN Message. Retrieved from http://www.dpsys120991.com/

Sims, Judith L. (2017). Senior Nutrition. Retrieved from Https://Www.Diet.Com/G/SeniorNutrition?Get=Senior-Nutrition

WHO Representative Office. (2013). Promoting Good Nutrition and Healthy Diet.

http://www.wpro.who.int/philippines/publications/modulez.pdf 